In all four this was predicted by daytime oximetry in a supine position, although only one had a low arterial oxygen saturation when sitting. This probably relates to the difference in posture and the less stressful nature of oximetry. Coincidental pulmonary disease probably related to smoking was present in only one of the patients with arterial oxygen desaturation.

This study shows that it is important to investigate patients with apparent and relative polycythaemia for oxygen desaturation not only by measuring daytime arterial blood gases but also by supine oximetry. Studies of the mechanisms of plasma volume control, which are altered in hypoxaemia, ${ }^{5}$ may help to determine whether the association of hypoxaemia and raised packed cell volume without an increased red cell mass is a causal one.

1 Moore-Gillon J, Treacher DF, Gaminara EJ, Pearson TC, Cameron IC Intermittent hypoxia in patients with unexplained polycythaemia. $B M Y$ 1986;293:588-90.

2 Messinezy $M$, Pearson TC. A retrospective study of apparent and relative polycythaemia: associated factors and early outcome. Clin Lab Haemato 1990;12:121-9.

3 Pearson TC, Guthrie DL. The interpretation of measured red cell mass and plasma volume in patients with elevated PCV values. Clin Lab Haematol 1984;6:207-17.

4 Berlin NI. Diagnosis and classification of polycythaemia. Semin Hematol 1975;12:339-51.

5 Eckstein JW, Horsley AW. Effects of hypoxia on peripheral venous tone in man. Journal of Laboratory and Clinical Investigation 1960;56:847-53.

(Accepted 2 October 1990)

\section{Prescribing of psychotropic drugs to children and adolescents}

\author{
Sue Adams
}

To date there have been no surveys of the prescribing of psychotropic drugs to children and adolescents, but this use of psychotropic drugs had been accepted since the first observations by Charles Bradley in 1937 that amphetamine sulphate (Benzedrine) modified the behaviour of children with severe behavioural disturbance. ${ }^{1}$ Since those early reports there have been more and more reports favouring the use of stimulants, ${ }^{2}$ tricyclic antidepressants (including their use for nocturnal enuresis), ${ }^{3}$ antipsychotic drugs in adolescent psychoses ${ }^{4}$ and lithium in adolescent manic depressive disorder. ${ }^{5}$ Minor tranquillisers and sedative antihistamines seem to be widely used to treat sleep disturbance, but there has been virtually no systematic investigation of this use. The aim of my study was to find how often these drugs are prescribed and the general pattern of drug type, indication, and prescriber.

\section{Patients, methods, and results}

The survey was based on a simple postal questionnaire (designed to maximise the response rate). Drugs were divided into seven different classes according to the drug group and indication for treatment (table). To

Numbers of prescriptions for psychotropic drugs given by 83 general practitioners and 22 consultant child psychiatrists in 3 month period to children aged $\leqslant 7,8-13$, and 14-17 years

\begin{tabular}{|c|c|c|c|c|c|c|}
\hline \multirow[b]{2}{*}{ Drug } & \multicolumn{3}{|c|}{$\begin{array}{l}\text { Prescribed by general } \\
\text { practitioners }\end{array}$} & \multicolumn{3}{|c|}{$\begin{array}{l}\text { Prescribed by } \\
\text { consultants }\end{array}$} \\
\hline & $\leqslant 7$ & 8-13 & $14-17$ & $\leqslant 7$ & $8-13$ & $14-17$ \\
\hline \multicolumn{7}{|l|}{ Tranquillisers: } \\
\hline Major & 0 & 0 & 2 & 1 & 3 & 18 \\
\hline Minor & 1 & 0 & 4 & 0 & 2 & 3 \\
\hline Hypnotics & 61 & 3 & 6 & 13 & 0 & 0 \\
\hline \multicolumn{7}{|l|}{ Antidepressants: } \\
\hline For depression & 3 & 2 & 9 & 0 & 4 & 9 \\
\hline For enuresis & 28 & 27 & 4 & 4 & 6 & 1 \\
\hline Lithium & 0 & 0 & 1 & 0 & 1 & 4 \\
\hline Stimulants & 0 & 0 & 0 & 1 & 3 & 0 \\
\hline
\end{tabular}

maintain the simple design of the questionnaire three age ranges were used, which were chosen to reflect the logical differences in prescribing with age. The age ranges were 7 years and under, 8-13, and 14-17 years, reflecting the infant and developmental period, childhood, and adolescence, respectively.

One hundred general practitioners randomly indentified from the current Wessex Family Health Services Authority list and all 28 consultant child psychiatrists in practice in Wessex were surveyed. The questionnaire inquired retrospectively about prescriptions given over the previous three months. It was ${ }_{\sigma}^{\omega}$ emphasised that only those prescriptions given on a $\bar{O}$ doctor's own initiative, rather than in response to 3 . another doctor's recommendation, should be counted. $\dot{\sigma}$ Those doctors who failed to reply were sent a second $N$ questionnaire.

Correctly completed replies were received from $83 \bigcirc$ general practitioners and 22 consultants. Sixty ي one general practitioners had given a total of $151 \mathrm{~V}$ prescriptions and 16 consultants 73 prescriptions. The table shows the numbers of prescriptions given in each N category.

\section{Comment}

This study provides some initial data about the $\vec{\theta}$ pattern of psychotropic drug prescribing to children and adolescents in both general practice and child $\sigma$ psychiatric practice. The response rate by both general practitioners and consultants was good, probably reflecting the simplicity of the questionnaire and the efforts made to encourage a reply. That in a three $\frac{\circ}{\mathbb{D}}$ month period as many as $73 \%$ of general practitioners $\stackrel{\varrho}{\Rightarrow}$ and $68 \%$ of consultant child psychiatrists prescribed a psychotropic drug to a child of 17 years or under was surprising and indicates a need for further studies. Perhaps there should also be some concern that several prescriptions of antidepressants for depression were made by general practitioners on their own initiative without the recommendation of a consultant. Also surprising is the prescribing of antidepressants for enuresis to so many children in the youngest age group, $\stackrel{8}{0}$ in whom such symptoms might be regarded as lying within the spectrum of normality. In addition, it is probably questionable whether young children or $N$ babies should be prescribed hypnotics for sleep $\rightarrow$ problems. There are dangers in prescribing psycho-o tropic drugs to children; in addition to the possibility of dangerous and unpleasant side effects there is 0 the risk of accidental poisoning and deliberate self $\omega$ harm by overdosing, which is a common adolescent problem.

I thank Dr Denis O'Leary and Dr Alastair Mackie for $\stackrel{\mathscr{C}}{?}$ supervision of this project.

1 Bradley C. The behaviour of children receiving Benzedrine. Am $\mathcal{f}$ Psychiatry 1937;94:577-85.

Rapoport JL. The use of drugs: trends in research. In: Rutter M, ed. Developmental neuropsychiatry. New York: Guildford Press, 1983:385-403, Shaffer D, Costello AJ, Hill LD. Control of enuresis with imipramine. Arch Dis Child 1968;43:665-71.

4 Steinberg D. Psychotic and other severe disorders in adolescence In: Ruter M Hersov L, eds. Child and adolescent psychiatry: modern approaches. Oxford: Hersov L, eds. Child and adolescent psychiatry:

5 Varanka TM, Weller RA, Weller EB, Fristad MA. Lithium treatment of manic episodes with psychotic features in prepubertal children. Am $\mathcal{F}$ Psychiatry 1988:145:1557-9.

(Accepted 12 October 1990) 